\title{
Impact of Acetochlor on Some Anatomic Parameters in the Leaves of Oriental Tobacco Plant (Nicotiana Tabacum L.)
}

\author{
Hristo Anastasov, Shtelijana Kalinova \\ Agricultural University, 4000 Plovdiv \\ Bulgaria
}

\begin{abstract}
In the testing grounds of the Tobacco and Tobacco Products Institute in Plovdiv, near the village of Markovo, in humus-carbonate soil, a field experiment was set up to determine the biological efficiency and selectivity of some soil herbicides used in growing oriental tobacco plants of the Plovdiv 7 variety. One of them was the Harnes herbicide with active ingredient acetochlor $90 \%$.

Acetochlor was applied at a dose of $150 \mathrm{ml} / \mathrm{dka}$ and $250 \mathrm{ml} / \mathrm{dka} 72$ hours prior to tobacco planting. During the vegetation period, some visible signs of phytotoxicity in the crop were observed - plant growth inhibition, leaf and vegetation tip deformation, weak chlorosis, etc.

For the purpose to determine the impact of the herbicide on tobacco leaf anatomy, samples from the midsection of the leaves were taken. The parameters taken into consideration were stomata number $/ \mathrm{mm}^{2}$ and stomata size ( $\mu \mathrm{m})$ from the upper and lower epidermis, and size of the assimilation parenchyma (mesophyll) of the leaf.

It was established that acetochlor caused considerable changes in the tobacco leaf anatomy, which found expression in reduction of stomata number $/ \mathrm{mm}^{2}$, as well as reduction of the thickness of leaf lamina (blade), compared to those in the non-treated control plants.
\end{abstract}

Keywords: acetochlor, phytotoxicity, tobacco leaf anatomy, stomata number $/ \mathrm{mm}^{2}$, mesophyll.

\section{INTRODUCTION}

Under the conditions of intensive development, agricultural production requires the use of herbicides for weed control in crops. Chemical agents that are applied often cause damage to agricultural crops, which in some cases are reversible in time, but sometimes lead to irreversible changes in the processes of growth and development of plants which could contribute to their perish (Miller et al., 1963; Martin, Fletcher, 1972; Gorske, Hopen, 1978; Muniyappa et al., 1980; Bakale, 1989; Ferrel et al., 1989; Tripathi et al., 1992; Mukharji, 1994; Kamble, 2007 a).

Anatomical changes in tissues and organs of crops, degeneration and malformations, reduction of content of chloroplasts in assimilation parenchyma of leaves, which may cause delays in their development may be added to the irreversible changes caused by herbicides (Guh, Kuk, 1997; Choi et al., 1998; Warabi et al., 2001; Ha et al., 2003; Jung et al., 2004; Yang et al., 2006; Kamble, 2007 b; Jung et al., 2008).

The purpose of this study was to determine the impact of acetochlor on some anatomic parameters in the leaves of the Oriental tobacco plant.

\section{Materials AND Methods}

In the testing grounds of the Tobacco and Tobacco Products Institute in Plovdiv, near the village of Markovo, in humus-carbonate soil, a field experiment was set up to determine the biological efficiency and selectivity of some soil herbicides used in growing oriental tobacco plants of the Plovdiv 7 variety. One of them was the Harnes herbicide with active ingredient acetochlor $90 \%$.

Acetochlor was applied at a dose of $150 \mathrm{ml} / \mathrm{dka}$ and $250 \mathrm{ml} / \mathrm{dka} 72$ hours prior to tobacco planting

During the vegetation period, some visible signs of phytotoxicity in the crop were observed - plant growth inhibition, leaf and vegetation tip deformation, weak chlorosis, etc.

For the purpose to determine the impacts of the herbicide on tobacco leaf anatomy, samples from the midsection of the leaves of the damaged plants and from the untreated control plants were taken and 
fixed in $70 \%$ Ethanol. To examine the anatomic parameters, an Amplival light microscope was used. The parameters taken into consideration were stomata number/ $\mathrm{mm}^{2}$ and stomata size $(\mu \mathrm{m})$ from the upper and lower epidermis, and size of the assimilation parenchyma (mesophyll) of the leaf - all at combined magnification of $400 \mathrm{X}$ (10X ocular and 40X objective). 30 measurements of each parameter were performed.

\section{RESUlts AND DisCUSSION}

The leaf of the tobacco plant (Nicotiana tabacum L.) is dorsoventral. Stomata are located on both sides of the leaf, characterizing it as amphistomatic. The basic epidermal cells are more or less isodiametric in shape, with undulated, curvy anticlinal walls. The stomatal complex is of the anomocytic type (lacking differentiated subsidiary cells), in which the stomata-surrounding cells are indistinguishable from the other epidermal cells, and the guard cells are bean-shaped.

The mesophyll is heterogeneous, represented by palisade (columnar) and loosely packed (spongy) parenchyma. The palisade parenchyma is located directly underneath the upper epidermis of the leaf. The spongy parenchyma consists of dispersedly situated, isodiametrically shaped parenchyma cells, interspersed with larger or smaller intercellular spaces, which are frequently connected to the stomata on the lower epidermis of the leaf.

Data about dimensions of the assimilation parenchyma (Table 1) on in control plants were significantly higher than those reported for the treated plants. The values for the thickness of the palisade parenchyma $(112,5) 127,6 \pm 1,79(147,5) \mu \mathrm{m}$, in untreated plants, were higher than the results obtained for acetochlor treated plants which were $(85) 95,7 \pm 1,31(112,5) \mu \mathrm{m}$ at the dose of $150 \mathrm{ml} / \mathrm{dka}$ and $(65) 72,2 \pm 0,97(82,5) \mu \mathrm{m}$ for the dose of $250 \mathrm{ml} / \mathrm{dka}$. Reduction of the thickness of columnar parenchyma was significant in plants, treated by a dose of $250 \mathrm{ml} / \mathrm{dka}$ acetochlor, which was confirmed by the average figures $-72,2 \mu \mathrm{m}$ for the treated and $127,6 \mu \mathrm{m}$ for the control plants.

Table1: Impact of acetochlor on some anatomic parameters in the leaves of oriental tobacco, cultivar Plovdiv 7

\begin{tabular}{|c|c|c|c|c|c|c|c|c|c|c|}
\hline \multicolumn{2}{|c|}{ Indexes } & ${ }_{(\min )} \bar{x} \pm \mathrm{S} \bar{x}_{(\max )}$ & $\mathrm{S}, \%$ & max:min & ${ }_{(\min )} \bar{x} \pm \mathrm{S} \bar{x}_{(\max )}$ & $\mathrm{S}, \%$ & max:min & ${ }_{(\min )} \bar{x} \pm S \bar{x}_{(\max )}$ & $\mathrm{S}, \%$ & max:min \\
\hline \multicolumn{2}{|c|}{ Variants } & \multicolumn{3}{|l|}{ non treated } & \multicolumn{3}{|c|}{ treated $-150 \mathrm{ml} / \mathrm{dka}$} & \multicolumn{3}{|c|}{ treated $-250 \mathrm{ml} / \mathrm{dka}$} \\
\hline & $\begin{array}{l}\text { palisade } \\
\text { parenchyma }\end{array}$ & $(112,5) 127,6 \pm 1,79(147,5)$ & 7,7 & 1,3 & $(85) 95,7 \pm 1,31(112,5)$ & 7,5 & 1,3 & $(65) 72,2 \pm 0,97(82,5)$ & 7,4 & 1,3 \\
\hline $\begin{array}{l}\text { leaf } \\
\text { parenchyma } \\
\text { (mesophyll), } \\
\mu \mathrm{m}\end{array}$ & $\begin{array}{l}\text { spongy } \\
\text { parenchyma }\end{array}$ & $(95) 128,9 \pm 1,76(147,5)$ & 7,5 & 1,5 & $(117,5) 133,9 \pm 1,8(152,5)$ & 7,4 & 1,3 & $(87,5) 98,9 \pm 1,14(112,5)$ & 6,3 & 1,3 \\
\hline \multirow{3}{*}{$\begin{array}{l}\text { ad } \\
\text { epidermis }\end{array}$} & number $/ \mathrm{mm}^{2}$ & $(83,3) 103,6 \pm 2,61(125)$ & 13.8 & 1.5 & $(58,3) 81,1 \pm 2,26(108,3)$ & 15,2 & 1,8 & $(41,6) 57,5 \pm 1,61(75)$ & 15,4 & 1,8 \\
\hline & length, $\mu \mathrm{m}$ & $(17,5) 27,8 \pm 0,75(35)$ & 14,9 & 2,0 & $(27,5) 32,4 \pm 0,54(37,5)$ & 9,1 & 1,4 & (25) $30,4 \pm 0,43(35)$ & 7,8 & 1,4 \\
\hline & width, $\mu \mathrm{m}$ & $(15) 22,8 \pm 0,49(27,5)$ & 11,8 & 1,8 & $(22,5) 26,25 \pm 0,42(30)$ & 8,9 & 1,3 & (20) $24,3 \pm 0,31(27,5)$ & 7,1 & 1,4 \\
\hline \multirow{3}{*}{$\begin{array}{l}\text { ab epidermis } \\
\text { stomata }\end{array}$} & number $/ \mathrm{mm}^{2}$ & $(108,3) 134,7 \pm 2,33(158,3)$ & 9,5 & 1,5 & $(141,6) 157,5 \pm 1,93(175)$ & 6,7 & 1,2 & $(141,6) 164,4 \pm 2,36(200)$ & 7,8 & 1,4 \\
\hline & length, $\mu \mathrm{m}$ & (20) $27,3 \pm 0,77(35)$ & 15,5 & 1,75 & $(22,5) 30,8 \pm 0,78(40)$ & 13,8 & 1,8 & $(22,5) 27,6 \pm 0,69(35)$ & 13,8 & 1,5 \\
\hline & width, $\mu \mathrm{m}$ & $(15) 22,7 \pm 0,67(30)$ & 16,4 & 2,0 & (20) $26,8 \pm 0,64(35)$ & 13,2 & 1,7 & (20) $23,1 \pm 0,35(27,5)$ & 8,4 & 1,4 \\
\hline
\end{tabular}

In spongy cell tissue increase of values was observed which was reported for the cases of plants, treated at the dose of $150 \mathrm{ml} / \mathrm{dka}(117,5) 133,9 \pm 1,8(152,5) \mu \mathrm{m}$, compared to control plants $(95) 128,9 \pm 1,76(147,5) \mu \mathrm{m}$, but at a dose of $250 \mathrm{ml} / \mathrm{dka}$ the results $(87,5) 98,9 \pm 1,14(112,5) \mu \mathrm{m}$ were significantly lower than the untreated plants, which was in line with the data for the palisade parenchyma and confirmed the adverse impacts of acetochlor on the thickness of mesophyll of the leaf and that was in close connection to the growth and development of plants.

The number of stomata in $\mathrm{mm}^{2}$ for adaxial (upper) epidermis with control plants $(83,3) 103,6 \pm 2$, $61(125)$ was bigger compared to the treated plants - $(58,3) 81,1 \pm 2,26(108,3)$ number $/ \mathrm{mm}^{2}$ stomata at the dose of $150 \mathrm{ml} / \mathrm{dka}$ and $(41,6) 57,5 \pm 1,61(75)$ number $/ \mathrm{mm}^{2}$ for the dose of $250 \mathrm{ml} / \mathrm{dka}$. Reduction of the number of stomata in treated plants was associated with the negative impact of acetochlor on them. In abaxial (lower) epidermis, increase of the number of stomata per $\mathrm{mm}^{2}$ in treated plants was registered, and the average values were 164,4 number $/ \mathrm{mm}^{2}$ stomata at the dose of $250 \mathrm{ml} / \mathrm{dka}, 157,5$ number $/ \mathrm{mm}^{2}$ of stomata at $150 \mathrm{ml} / \mathrm{dka}$ and 134,7 number $/ \mathrm{mm}^{2}$ of stomata reported in untreated plants. Increase of the number of stomata in treated plants was due both to their relatively large number per unit of area for the lower epidermis compared to the upper and to the adverse impacts of acetochlor on them and on the significant deformation of the leaf blade of those. Adverse impact of the herbicide 
was confirmed by the increased values of the length and width of the stomata in the upper and lower epidermis in treated plants, which was associated with atrophy of closing cells of the stomata and improper operation of the stomata apparatus.

Reduction of the leaf parenchyma thickness of the leaves of tobacco plants treated with acetochlor, reduction of the number of stomata of adaxial epidermis and their increase by the abaxial as well as the increase of their size, was due to the adverse impact of the herbicide on them, and that was related to their feeding, growth and development. Visible signs of that influence were retarded growth, deformation of leaves and vegetation peak, weak chlorosis.

\section{Conclusions}

Acetochlor reduces thickness of the assimilation parenchyma of leaves it causes reduction of the number of stomata per $\mathrm{mm}^{2}$ of the upper epidermis and their increase in the lower epidermis and causes atrophy of the closing cells of stomata and leaf blades of the Oriental tobacco plants of the Plovdiv 7 variety.

\section{REFERENCES}

[1] Bakale, V.L. (1989). Spray effects of herbicides on Xanthium strumarium Linn. The Botanique, 10 (1-4), pp. 53 - 65.

[2] Choi, K.W., Han, O., Lee, H.J., Yun, Y.C., Moon, Y.H., Kim, M., Kuk, Y.I., Guh, J.O. (1998). Generation of resistance to the diphenyl ether herbicide, oxyfluorfen, via expression of the Bacillus subtilis protoporphyrinogen oxidase gene in transgenic tobacco plants. Biosci. Biotechnol. Biochem.,62, pp.558 - 560.

[3] Ferrel, M.A., Whittson, T.D., Alley, H.P. (1989). Control of Euphorbia esula with growth regulators herbicide combinations. Weed Technology, 3, pp. $479-484$.

[4] Gorske, S.F., Hopen, H.J. (1978). Effect of two-diphenyl herbicide on Portulaca oleracea. Weed Science, 26, pp. 585 - 588.

[5] Guh, J.O., Kuk Y.I. (1997). Difference in absorption and anatomical responses to protoporphyrinogen oxidaseinhibiting herbicides in wheat and barley. Korean Journal of Crop Science 42(1), pp. $68-78$.

[6] Ha, S.B., Lee, S.B., Lee, D.E., Guh, J.O., Back, K. (2003). Transgenic rice plants expressing Bacillus protoporphyrinogen oxidase gene show low herbicide oxyfluorfen resistance. Biol. Plant., 47, pp. $277-280$.

[7] Jung, H.I., Kuk, Y.I., Back, K., Burgos, N.R. (2008). Resistance pattern and antioxidant enzyme profiles of protoporphyrinogen oxidase (PROTOX) inhibitorresistant transgenic rice. Pesticide Biochemistry and Physiology, 91(1), pp. $53-65$.

[8] Jung, S., Lee, Y., Yang, K., Lee, S.B., Jang, S.M., Ha, B., Back, K.(2004). Dual targeting of Myxococcus xanthus protoporphyrinogen oxidase into chloroplast and mitochondria and high level oxyfluorfen resistance. Plant Cell Environ, 27, pp. 1436 - 1446.

[9] Kamble, S.I. (2007 a). Effect of spray application of oxyfluorfen on anatomical characters of Hibiscus cannabinus Linn. Biosciences Biotechnology Research Asia, 4(2), pp. 671- 674.

[10] Kamble, S.I. (2007 b). Effect of spray application of 2,4-D on morphological characters of Hibiscus cannabinus Linn. Biosciences Biotechnology Research Asia, 4(2), pp. 705 - 712.

[11] Martin, J.A., Fletcher, J.J.(1972). The effect of sublethal doses of various herbicides on lettuce. Weed Res, 12, pp. 268 - 271.

[12] Miller, T.H., Kempner, H.M., Wilkerson, J.A., Roy, C.L. (1963). Response of cotton to 2,4-D and related phenoxy herbicide. Tech. Bull. Us. Dep. Agric, 1289, p.28.

[13] Mukharji, A. (1994). Effects of certain phenoxy herbicides on mortality, growth and seed output of Abutilon indicum(Linn.) S.W. Acta Botanika Hungarika, 38 (1-4), pp. 335 - 343.

[14] Muniyappa, T.V., Ramchandra Prasad, T.V., Krishnamurthy, K.(1980). Comparative effectiveness of mechanical and chemical method of control of Parthenium hysterophorus Linn. Indian J. Weed Sci, 12(2), pp. 137 - 144.

[15] Tripathi, B., Verma, T.S., Sharma, H.L. (1992). Chemical control of Lantana camera and its use as organic manure. Indian J. Agron. Sci, 37(1),pp. 135 - 139. 
[16] Warabi, E., Usui, K., Tanaka, Y., Matsumoto, H. (2001). Resistance of a soybean cell line to oxyfluorfen by overproduction of mitochondrial protoporphyrinogen oxidase. Pestic. Manag.Sci., 57, pp. 743 - 748.

[17] Yang, K., Jung, S., Lee, Y., Back, K. (2006). Modifying Myxococcus xanthus protoporphyrinogen oxidase to plant codon usage and high level of oxyfluorfen resistance in transgenic rice. Pestic. Biochem. Physiol., 86, pp. 186 - 194. 